\title{
ANALISIS PROYEKSI SEKTOR PERTANIAN DI PROVINSI MALUKU UTARA
}

\author{
Disusun oleh : \\ Karmila Ibrahim \\ Dosen Fakultas Pertanian - Universitas Khairun
}

\begin{abstract}
Analisis LQ Sektor pertanian, subsektor tanaman pangan, perkebunan, kehutanan dan perikanan merupakan subsektor unggulan. namun keunggulan alokasi yang bernilai negatif menunjukkan bahwa subsektor perkebunan tidak memiliki keunggulan alokasi tapi memiliki keunggulan kompetitif, sehingga subsektor perkebunan merupakan subsektor unggulan pada sektor pertanian di Provinsi Maluku Utara. Dari analisis trend kontribusi sektor pertanian menunjukkan kecendrungan garis trend yang negatif, artinya bahwa trend kontribusi PDRB sektor pertanian menurun.
\end{abstract}

\section{Kata Kunci : LQ, Pertanian}

\section{PENDAHULUAN}

\section{Latar Belakang}

Pembangunan pertanian sebagai bagian integral dari Pembangunan Nasional mempunyai peranan yang strategis dalam pemulihan ekonomi nasional. Peranan strategis tersebut khususnya adalah dalam peningkatan pendapatan daerah, penyediaan pangan, penyediaan bahan baku industri, peningkatan ekspor dan devisa negara, penyediaan kesempatan kerja dan kesempatan berusaha, peningkatan pendapatan petani dan kesejahteraan masyarakat. Salah satu cara untuk mengetahui keberhasilan pembangunan pertanian adalah dengan menganalisis pendapatan suatu daerah. Analisa pendapatan tersebut bisa berupa analisis internal Pendapatan Domestik Regional Bruto (PDRB) ataupun dengan Pendapatan Domestik Bruto (PDB). PDB adalah kemampuan suatu negara dalam menghasilkan pendapatan atau balas jasa kepada faktor-faktor yang ikut berpartisipasi dalam proses produksi negara tersebut. PDRB adalah kemampuan suatu daerah dalam menghasilkan pendapatan atau balas jasa kepada faktor-faktor yang

ikut berpastisipasi dalam proses produksi di daerah tersebut. Penghitungan pendapatan ini menggunakan konsep domestik yang berarti seluruh nilai tambah yang ditimbulkan oleh berbagai sektor atau lapangan usaha yang melakukan kegiatan usaha diwilayah atau region dimasukkan tanpa memperhatikan pemilikan atas faktor produksi (BPS, 2005).

Provinsi Maluku Utara merupakan Provinsi kepulauan dengan luas total wilayah 145.801,1 km²., sebagian besar merupakan wilayah laut, yaitu seluas $100.731,44 \mathrm{~km}^{2}$ (69,08\%), sisanya seluas 45.069,66 km2 (30,92\%) adalah daratan. Provinsi Maluku Utara terbagi menjadi 7 Kabupaten dan 2 kota. Dari hasil Survei Penduduk Antar Sensus (Supas) 2006, diketahui bahwa jumlah penduduk Maluku Utara sebanyak 919.160 jiwa yang terdiri dari 469.874 jiwa laki-laki dan 449.286 jiwa perempuan. Secara keseluruhan penggunaan lahan untuk tanaman pangan seluas $178.886 \mathrm{Ha}$, tanaman perkebunan seluas 3,199.932 $\mathrm{Ha}$, dan 
kawasan hutan seluas 3,184.725 Ha. Provinsi Maluku Utara didominasi oleh penggunaan lahan hutan dan lahan perkebunan. Dengan penggunaan lahan, struktur ekonomi Maluku Utara Tahun 2005 didominasi oleh tiga sektor yaitu sektor Pertanian, sektor Perdagangan, Hotel dan Restoran serta sektor Industri Pengolahan (BAPPEDA, 2006).

Struktur ekonomi Maluku Utara ditunjukkan melalui peranan setiap sektor terhadap total PDRB. Kontribusi tersebut mencerminkan kemampuan setiap sektor dalam menciptakan barang dan jasa dalam rangka pembentukan nilai tambah. Pertumbuhan ekonomi Maluku Utara tahun 2006 sebesar 5,48\% yaitu karena terjadi kenaikan PDRB atas dasar harga konstan dari 2.236,80 milyar rupiah pada tahun 2005 menjadi 2.359,48 milyar rupiah. Jika dibandingkan dengan tahun sebelumnya, pertumbuhan ekonomi tahun 2006 lebih tinggi dari tahun 2005 yaitu pertumbuhannya sebesar $\quad 5,10 \%$ (BPS, 2006). Meningkatnya pertumbuhan ekonomi Maluku Utara tahun 2006 diantaranya didorong oleh pertumbuhan positif di seluruh sektor, terutama pada sektor bangunan/konstruksi dengan pertumbuhan terbesar yaitu $11,35 \%$ (BPS, 2006). Adapun sektor pertanian yang merupakan sektor unggulan Maluku Utara hanya mengalami pertumbuhan 4,75\% dengan PDRB sebesar 830,361 milyar rupiah (BPS, 2006).

\section{Perumusan Masalah}

Dalam proses pembangunan diperlukan konsep keterpaduan antar sektor pertanian maupun non pertanian. Secara ideal, output suatu sektor akan digunakan sebagai input bagi sektor lain, dengan demikian terdapat hubungan yang saling mempengaruhi diantara sektor dalam suatu perekonomian pada kurun waktu tertentu, sehingga kemajuan pada suatu sektor tidak akan bisa terwujud tanpa dukungan sektor yang lain.

Sektor pertanian provinsi Maluku Utara masih berperan penting dalam perekonomian Maluku Utara, baik dalam kontribusi sumbangan sektor pertanian terhadap keseluruhan PDRB Provinsi dan juga kemampuannya dalam menyerap tenaga kerja yang ada. Pembangunan pertanian pada masingmasing subsektor memperkuat petani, pelaku agribisnis lainnya dan aparatur pertanian dengan memanfaatkan keunggulan subsektor masing-masing daerah kabupaten/Kota.

Berdasarkan latar belakang dan uraian diatas maka dapat dirumuskan permasalahan sebagai berikut :

1. Apakah yang menjadi subsektor unggulan pertanian di tingkat Provinsi Maluku Utara.

2. Bagaimana trend sub sektor pertanian di Provinsi Maluku Utara

\section{Tujuan Penelitian}

1. Untuk mengetahui subsektor unggulan sektor pertanian Provinsi Maluku Utara

2. Untuk mengetahui trend subsektor pertanian di Provinsi Maluku Utara

\section{METODE PENELITIAN}

\section{Metode Dasar Penelitian}

Metode dasar yang digunakan dalam penelitian ini adalah metode deskriptif analitis. Penelitian deskriptif adalah studi untuk menemukan fakta dengan interpretasi yang tepat berdasarkan data-data, bersifat eksploratif yang bertujuan untuk 
mengenal fenomena untuk penelitian selanjutnya.

\section{Metode Penentuan Obyek Penelitian}

Pemilihan sektor yang diteliti dilakukan secara purposif, yaitu dengan sengaja sektor yang akan diteliti untuk menggambarkan beberapa sifat dari sektor tersebut. Sektor pertanian dan subsektornya dipilih karena sektor pertanian merupakan sektor andalan disebagian besar wilayah Maluku Utara.

\section{Teknik Pengumpulan Data}

Teknik pengumpulan data yang dilakukan adalah melalui pencatatan dan pengumpulan data sekunder maupun informasi dari instansi yang terkait seperti BPS, BAPPEDA, Dinas Pertanian dan Tanaman Pangan, Dinas Perikanan dan Kelautan, dan Dinas Kehutanan di wilayah Provinsi Maluku Utara serta instansi lainnya yang terkait dengan penelitian ini.

\section{Jenis Data}

Data yang diperlukan adalah PDRB atas dasar harga konstan tahun 2000 untuk Provinsi dan Kabupaten/Kota di Maluku Utara.

\section{Asumsi dan Pembatasan Masalah}

1. Data yang dipergunakan adalah PDRB sektor dan subsektor pertanian berdasarkan harga konstan tahun dasar 2000.

2. Penelitian dibatasi berdasarkan data selama 6 tahun yaitu periode tahun 2000-2006 untuk Provinsi dan Kabupaten/Kota di Provinsi Maluku Utara.

\section{Konseptualitas dan Pengukuran Variabel}

Beberapa istilah yang digunakan dalam penulisan ini adalah :

1. Produk Domestik Regional bruto (PDRB) adalah jumlah nilai barang dan jasa yang dihasilkan oleh berbagai unit produksi pada suatu wilayah dalam jangka waktu tertentu (biasanya 1 tahun), (BPS, 2005).

2. Produk Domestik Regional Bruto (PDRB) atas dasar harga konstan adalah jumlah seluruh agregat ekonomi yang dinilai atas dasar harga yag terjadi pada tahun dasar yaitu dalam hal ini tahun 2000,.(BPS, 2005).

3. Subsektor pertanian adalah merupakan bagian dari sektor menurut lapangan usaha yang ada dalam PDRB.

4. Sektor unggulan adalah sektor yang dapat mendorong pertumbuhan ekonomi wilayah atau sektor yang dapat menghasilkan produk maupun penyedia jasa dari luar wilayah. (Zam,2002).

5. Sektor non unggulan adalah sektor yang menghasilkan produk hanya untuk memenuhi kebutuhan konsumsi lokal. (Zam, 2002).

6. Laju pertumbuhan ekonomi adalah proses perubahan output per kapita dalam jangka panjang. (Zam, 2002).

7. Keunggulan kompetitif adalah kemampuan suatu daerah atau wilayah untuk memasarkan produknya diluar daerah yang disebabkan oleh adanya sumberdaya alam yang dimiliki 
wilayah tersebut. (Tarigan, 2005).

\section{Metode Analisis}

\section{Identifikasi Subsektor Basis}

\section{Analisis Location Quotient (LQ)}

Analisis LQ merupakan salah satu pendekatan tidak langsung yang digunakan untuk mengetahui apakah suatu sektor atau komoditas merupakan sektor basis atau non-basis. Dengan kata lain, nilai LQ akan memberikan indikasi kemampuan suatu daerah dalam menghasilkan suatu komoditas, apakah mempunyai potensi untuk mensuply daerah lain, mendatangkan dari daerah lain, atau dalam keadaan seimbang (Isard, 1960). Secara matematis formula LQ adalah sebagai berikut:

$$
L Q=\frac{Y_{i j} / Y_{j}}{Y_{i} / Y}
$$

Keterangan :

$\mathrm{Y}_{\mathrm{ij}}$ : PDRB sektor/subsektor i di Provinsi Maluku Utara

$\mathrm{Y}_{\mathrm{j}}$ : Total PDRB Provinsi Maluku Utara

$\mathrm{Y}_{\mathrm{i}}$ : PDRB sektor/subsektor i di tingkat Nasional

$\mathrm{Y}$ : Total PDRB di tingkat Nasional

Dari hasil perhitungan LQ dapat diketahui bahwa :

1. Jika LQ $>1$, berarti sektor tersebut merupakan sektor basis atau sektor unggul di Provinsi Maluku Utara

2. Jika $L Q<1$, berarti sektor tersebut merupakan sektor non basis atau sektor non unggul.

\section{Analisis Proyeksi PDRB}

Proyeksi angka PDRB dilakukan dengan membuat persamaan trend PDRB. Garis trend pada dasarnya adalah garis regresi variabel bebas (x) merupakan variabel waktu. Garis regresi maupun trend dapat berupa garis lurus (linier regression/trend) maupun tidak lurus (non linier regression trend). Garis trend dapat dipergunakan untuk membuat ramalan yang sangat diperlukan untuk dasar perumusan perencanaan, analisis yang digunakan adalah analisis regresi sederhana. Fungsi yang dapat digunakan adalah linier, kuadratik, logaritmik dan eksponensial. Modelnya adalah sebagai berikut. (Supranto, 2000). Modelnya adalah sebagai berikut.

1. $\mathrm{Y}$

2. $\mathrm{Y}$

$=\mathrm{a}_{0}+\mathrm{a}_{1} \mathrm{~T}$

$=\mathrm{a}_{0}+\mathrm{a}_{1} \mathrm{~T}+\mathrm{a}_{2} \mathrm{~T}^{2}$

3. $\mathrm{Y}$

4. $\log Y$

$=a_{0}+a_{1} T+a_{2} T^{2}+a_{3} T^{3}$

Keterangan :

$\mathrm{Y}: \mathrm{PDRB}$

$\mathrm{a}_{0}$ : Konstanta/Intersep

$\mathrm{a}_{\mathrm{n}}$ : Koefisien/Slope

$\mathrm{T}$ : Waktu

Pengujian model dilakukan dengan uji $\mathrm{R}^{2}$, uji F dan uji t (Gujarati,1999). Uji R ${ }^{2}$ dilakukan untuk mengetahui sebaik mana garis regresi sampel mencocokkan data. Nilai $\mathrm{R}^{2}$ menyatakan proporsi variasi dalam variabel tidak bebas yang dijelaskan oleh variabel yang menjelaskan. Bila nilai $\mathrm{R}^{2}$ semakin mendekati 1 artinya garis regresi semakin baik. Rumus uji $\mathrm{R}^{2}$ adalah sebagai berikut :

$$
R^{2}=\frac{\sum(\hat{Y}-\bar{Y})^{2}}{\sum\left(Y_{t}-\bar{Y}\right)^{2}}=\frac{E S S}{T S S}
$$

Keterangan :

ESS : Explained Sum of Square atau jumlah kuadrat dijelaskan

RSS : Residual Sum of Square atau jumlah kuadrat sisa

TSS : Total Sum of Square atau jumlah kuadrat total ESS + RSS

Uji $\mathrm{F}$ digunakan untuk mengetahui pengaruh semua variabel bebas secara bersama-sama terhadap variabel tidak bebas. Rumus uji $\mathrm{F}$ adalah :

Ho : $\beta_{1}=0$

$\mathrm{H}_{1}: \beta_{1} \neq 0$

F.hit : $\frac{E S S /(k-1)}{R S S /(n-k)}$, F.tabel : ( $\alpha, \mathrm{k}-1, \mathrm{n}-$

k)

Keterangan :

$\mathrm{n}$ : jumlah sampel

$\mathrm{k}$ : jumlah variabel

Kriteria pengujian :

Ho di tolak jika F hit $>$ F tabel

Ho di terima jika $F$ hit $<$ F tabel 
Uji t digunakan untuk mengetahui pengaruh hubungan antara variabel bebas terhadap variabel tidak bebas. Rumusnya sebagai berikut :

Ho : $\beta_{1}=0$

$\mathrm{H}_{1}: \beta_{1} \neq 0$

t.hit $=\frac{\beta_{i}}{\operatorname{se}\left(\hat{\beta}_{i}\right)}$, F.tabel $:(\alpha / 2, \mathrm{~N}-\mathrm{k})$

Keterangan :

$\beta_{\mathrm{i}} \quad$ : parameter yang diestimasi

se $\hat{\beta}_{i}$ : standard error parameter yang diestimasi

Kriteria pengujian :

Ho di tolak jika t hit $>\mathrm{t}$ tabel

Ho di terima jika $\mathrm{t}$ hit $<\mathrm{t}$ tabel

\section{PEMBAHASAN}

\section{Identifikasi Subsektor Unggulan dan Non Unggulan Sektor Pertanian}

Perekonomian daerah sangat dipengaruhi oleh jumlah sektor yang memiliki keunggulan (sektor unggulan) yaitu sektor yang berpotensi untuk mengembangkan daerah. Sektor unggulan menghasilkan barang dan jasa baik untuk pasar di daerah maupun di luar daerah. Penjualan barang dan jasa akan meningkatkan pendapatan daerah dan masyarakat setempat.

Untuk mengetahui sektor maupun subsektor pertanian yang menjadi unggulan dalam perekonomian Maluku Utara antara lain dengan menggunakan analisis Location Quotient. Analisis ini digunakan untuk menentukan sektor atau subsektor yang merupakan sektor yang dapat mengekspor dalam perekonomian Maluku Utara. LQ adalah suatu indikator sederhana yang menunjukkan kekuatan atau besar kecilnya peranan suatu subsektor pada daerah dibandingkan dengan peranan subsektor yang sama di daerah referensi (Nasional).

\section{Location Quotient}

Penggunaan teknik analisis Location Quotient (LQ) merupakan cara sederhana untuk mengetahui kemampuan Provinsi Maluku Utara dalam menentukan sektor atau subsektor unggulan dengan membandingkannya dengan sektor atau subsektor yang sama pada tingkat nasional.

Hasil analisis Location Quotient (LQ) terhadap PDRB Provinsi Maluku Utara selama periode penelitian (20002006) dapat dilihat pada Tabel 4.1.1 yang menyajikan hasil analisis LQ sektor pertanian dan subsektornya. 
Tabel 1. Hasil Analisis Location Quotient (LQ) Sektor Pertanian Provinsi Maluku Utara Tahun 2000-2006.

\begin{tabular}{|l|l|l|l|l|l|l|l|l|l|}
\hline Sub Sektor & 2000 & 2001 & 2002 & 2003 & 2004 & 2005 & 2006 & $\begin{array}{l}\text { Rata- } \\
\text { rata }\end{array}$ & Krit \\
\hline Pertanian & 2.14 & 2.03 & 2.09 & 2.15 & 2.16 & 2.23 & 2.29 & 2.16 & $\mathrm{U}$ \\
\hline a.Tanaman Pangan & 1.14 & 1.11 & 1.14 & 1.15 & 1.16 & 1.19 & 1.20 & 1.16 & $\mathrm{NU}$ \\
\hline b. Perkebunan & 6.29 & 6.32 & 6.31 & 6.58 & 6.69 & 6.99 & 7.31 & 6.64 & $\mathrm{U}$ \\
\hline c.Peternakan & 0.89 & 0.71 & 0.72 & 0.71 & 0.71 & 0.72 & 0.71 & 0.74 & $\mathrm{NU}$ \\
\hline d. Kehutanan & 1.45 & 1.73 & 1.89 & 1.97 & 1.97 & 2.23 & 2.47 & 1.97 & $\mathrm{U}$ \\
\hline e. Perikanan & 2.61 & 1.94 & 2.00 & 1.98 & 1.98 & 1.95 & 1.93 & 2.05 & $\mathrm{U}$ \\
\hline
\end{tabular}

Tabel 1 diketahui bahwa sektor pertanian memiliki koefisien LQ lebih dari satu yaitu 2.16, ini menunjukkan bahwa sektor pertanian merupakan sektor unggulan di Provinsi Maluku Utara yang mampu memenuhi kebutuhan daerah, juga dapat mengekspor ke daerah lain. Sektor pertanian terdiri dari lima subsektor, sebagian merupakan subsektor unggulan yaitu subsektor Tanaman Pangan, Tanaman Perkebunan, Kehutanan dan Perikanan, masing masing memiliki nilai koefisien LQ lebih dari satu yaitu 1, 16; 6,64; 1,97 dan 2,05. Kecuali subsektor peternakan dengan nilai koefisien LQ kurang dari satu yaitu 0,74. Bahwa keeempat subsektor tersebut dapat menunjang sektor pertanian Maluku Utara.

Subsektor peternakan masuk dalam kualifikasi relatif tertinggal karena kontribusinya yang lebih kecil dari subsektor yang sama ditingkat nasional maupun laju pertumbuhan subsektornya yang lebih kecil dari laju pertumbuhan subsektor peternakan di tingkat nasional. Potensi lahan yang dimiliki serta mayoritas masyarakat petani yang mengusahakan tanaman perkebunan dan tanaman pangan merupakan salah satu faktor sektor perkebunan dan tanaman pangan maju dan tumbuh cepat, luas hutan dan potensi sumberdaya hutan yang dimiliki memacu subsektor kehutanan lebih maju. Subsektor perikanan merupakan salah satu sektor andalan disamping potensi kelautan yang dimiliki, perikanan merupakan mata pencaharian andalan masyarakat Maluku Utara, namun dalam pemeliharaan dan pengolahan hasil laut sendiri masih bersifat sederhana dan cara penangkapan hasil laut yang dapat mengancam ekosistem dan biota laut sehingga subsektor perikanan adalah subsektor yang maju tapi tertekan.

\section{Trend Kontribusi Sektor Pertanian PDRB Provinsi Maluku Utara \\ 1. Sektor Pertanian}

Analisis trend dilakukan pada kontribusi PDRB sektor pertanian dan subsektor pertanian Provinsi Maluku Utara atas dasar harga konstan tahun 2000. Trend sektor pertanian mengikuti pola trend kuadratik, uji persamaannya adalah signifikan pada tingkat kepercayaan 95\%. Hasil analisis sektor pertanian lengkapnya dapat dilihat pada tabel Anova dibawah ini. 
Tabel 2. Variabel, Koefisien dan Hasil Perhitungan Anova Kontribusi Sektor Pertanian PDRB Maluku Utara Tahun 20002006.

\begin{tabular}{|llll|}
\hline Variabel & Koefisien & T hitung & Sign T \\
\hline Konstanta & 35,226*** & 120,226 & 0,000 \\
$\mathrm{~T}$ & $0,478^{* *}$ & 2,849 & 0,046 \\
$\mathrm{~T}^{2}$ & $-0,071^{* *}$ & $-3,453$ & 0,026 \\
\hline $\mathrm{R}^{2}$ & $: 0,819$ & $\mathrm{~F}$ hitung & $\mathrm{SE} \quad:$ \\
& & $: 9,043$ & 0,188 \\
$\mathrm{R}^{2}$ & $: 0,728$ & Sign F & \\
adjusted & & $: 0,033$ & \\
\hline
\end{tabular}

Sumber : Data Sekunder diolah (2008).

Keterangan :

** signifikan pada tingkat kepercayaan 95\%

*** signifikan pada tingkat kepercayaan 99\%

Hasil uji t menunjukkan bahwa konstanta $\mathrm{T}$ dan $\mathrm{T}^{2}$ signifikan pada tingkat kepercayaan 95\%. $\mathrm{R}^{2}$ persamaannya adalah 0,819 artinya bahwa 81,9\% kontribusi sektor pertanian dapat dijelaskan oleh waktu yang dimasukkan dalam model, sedangkan 18,1\% dijelaskan oleh variabel lain. Garis trend yang negatif menunjukkan bahwa kontribusi sektor pertanian terhadap PDRB pada masa yang akan datang cenderung menurun. Potensi sumberdaya alam yang melimpah namun tidak didukung dengan pengolahan, serta penggunaan tekonologi yang tepat guna akan menyebabkan penurunan produksi pada sektor pertanian.

\section{Subsektor Tanaman Pangan}

Trend subsektor tanaman pangan mengikuti pola trend linier, uji persamaannya adalah signifikan pada tingkat kepercayaan 99\%. Hasil analisis subsektor tanaman pangan lengkapnya dapat dilihat pada tabel Anova dibawah ini.

Tabel 3. Variabel, Koefisien dan Hasil Perhitungan Anova Kontribusi Subsektor Tanaman Pangan
PDRB Maluku Utara Tahun 2000-2006.

\begin{tabular}{|lllll|}
\hline Variabel & Koefisien & T hitung & Sign T \\
\hline Konstanta & $10,084^{* * *}$ & 208,544 & 0,000 \\
$\mathrm{~T}$ & $-0,131^{* * *}$ & $-12,122$ & 0,000 & \\
& & & \\
\hline & $: 0,967$ & F hitung : & SE & $:$ \\
$\mathrm{R}^{2}$ & 146,944 & 0,057 & \\
$\mathrm{R}^{2}$ & $: 0,961$ & Sign $\mathrm{F}$ & $:$ \\
adjusted & \multicolumn{4}{c}{0,000} \\
\hline Sumber & $:$ Data Sekunder diolah (2008). \\
Keterangan : \\
*** signifikan pada tingkat kepercayaan 99\% \\
\multicolumn{4}{c}{ Hasil uji t menunjukkan bahwa }
\end{tabular}

konstanta $\mathrm{T}$ signifikan pada tingkat kepercayaan 99\%. $\mathrm{R}^{2}$ persamaannya adalah 0,967 artinya bahwa 96,7\% variasi kontribusi subsektor tanaman pangan dapat dijelaskan oleh variabel waktu yang dimasukkan dalam model, sedangkan 3,3\% dapat dijelaskan oleh variabel lain. Garis trend yang negatif menunjukkan bahwa kontribusi subsektor tanaman pangan terhadap PDRB sektor pertanian cenderung menurun.

\section{Subsektor Perkebunan}

Trend subsektor perkebunan mengikuti pola trend logaritmik, uji persamaannya adalah signifikan pada tingkat kepercayaan 99\%. Hasil analisis subsektor perkebunan lengkapnya dapat dilihat pada tabel Anova dibawah ini.

Tabel 4. Variabel, Koefisien dan Hasil

Perhitungan Anova Kontribusi

Subsektor Perkebunan PDRB

Maluku Utara Tahun 20002006.

\begin{tabular}{|c|c|c|c|}
\hline Variabel & Koefisien & T hitung & Sign T \\
\hline Konstanta & $16,995 * * *$ & 108,932 & 0,000 \\
\hline $\mathrm{T}$ & $0,386 * *$ & 3,401 & 0,019 \\
\hline $\mathrm{R}^{2}$ & $: 0,698$ & $\begin{array}{l}\text { F hitung : } \\
11,564\end{array}$ & $\begin{array}{l}\text { SE } \\
0,191\end{array}$ \\
\hline $\begin{array}{l}\mathrm{R}^{2} \\
\text { adjusted }\end{array}$ & : 0,638 & $\begin{array}{l}\text { Sign F : } \\
0,019\end{array}$ & \\
\hline
\end{tabular}


Hasil uji t menunjukkan bahwa konstanta $\mathrm{T}$ signifikan pada tingkat kepercayaan 95\%. $\mathrm{R}^{2}$ persamaannya adalah 0,698 artinya bahwa 69,8\% variasi kontribusi subsektor perkebunan dapat dijelaskan oleh variabel waktu yang dimasukkan dalam model, sedangkan 30,2\% dapat dijelaskan oleh variabel lain. Garis trend yang positif menunjukkan bahwa kontribusi sektor pertanian terhadap PDRB cenderung meningkat. Mayoritas petani yang mengusahakan tanaman perkebunan, sebagai mata pencaharaian utama mendorong pemerintah daerah mengupayakan teknologi sehingga dapat meningkatkan produksi tanaman perkebunan.

\section{Subsektor Peternakan}

Trend subsektor peternakan mengikuti pola trend kuadratik, uji persamaannya adalah signifikan pada tingkat kepercayaan 99\%. Hasil analisis sektor peternakan lengkapnya dapat dilihat pada tabel Anova dibawah ini.

Tabel 5. Variabel, Koefisien dan Hasil Perhitungan Anova Kontribusi Subsektor Peternakan PDRB Maluku Utara Tahun 20002006.

\begin{tabular}{|c|c|c|c|}
\hline Variabel & Koefisien & T hitung & Sign $T$ \\
\hline Konstanta & $1,514 * * *$ & 70,187 & 0,000 \\
\hline $\mathrm{T}$ & $0,032 * *$ & $-4,650$ & 0,059 \\
\hline $\mathrm{T}^{2}$ & $-0,007 * *$ & 2,609 & 0,010 \\
\hline $\mathrm{R}^{2}$ & : 0,963 & F hitung : & SE \\
\hline $\begin{array}{l}\mathrm{R}^{2} \\
\text { adjusted }\end{array}$ & : 0,945 & $\begin{array}{l}\text { Sign F } \\
0,001\end{array}$ & \\
\hline \multicolumn{4}{|c|}{$\begin{array}{l}\text { Sumber : Data Sekunder diolah (2008). } \\
\text { Keterangan : } \\
* * \text { signifikan pada tingkat kepercayaan 95\% } \\
\text { *** signifikan pada tingkat kepercayaan 99\% }\end{array}$} \\
\hline
\end{tabular}

Hasil uji t menunjukkan bahwa konstanta $\mathrm{T}$ dan $\mathrm{T}^{2}$ signifikan pada tingkat kepercayaan 95\%. $\mathrm{R}^{2}$ persamaannya adalah 0,963 artinya bahwa 96,3\% variasi kontribusi subsektor peternakan dapat dijelaskan oleh variabel waktu sedangkan 3,7\% dapat dijelaskan oleh variabel lain yang dimasukkan dalam model. Garis trend yang negatif menunjukkan bahwa kontribusi subsektor peternakan terhadap PDRB cenderung menurun.

\section{Subsektor Kehutanan}

Trend sektor pertanian mengikuti pola trend logaritmik, uji persamaannya adalah signifikan pada tingkat kepercayaan 90\%. Hasil analisis subsektor kehutanan lengkapnya dapat dilihat pada tabel Anova dibawah ini.

Tabel 6. Variabel, Koefisien dan Hasil Perhitungan Anova Kontribusi Subsektor Kehutanan PDRB Maluku Utara Tahun 20002006.

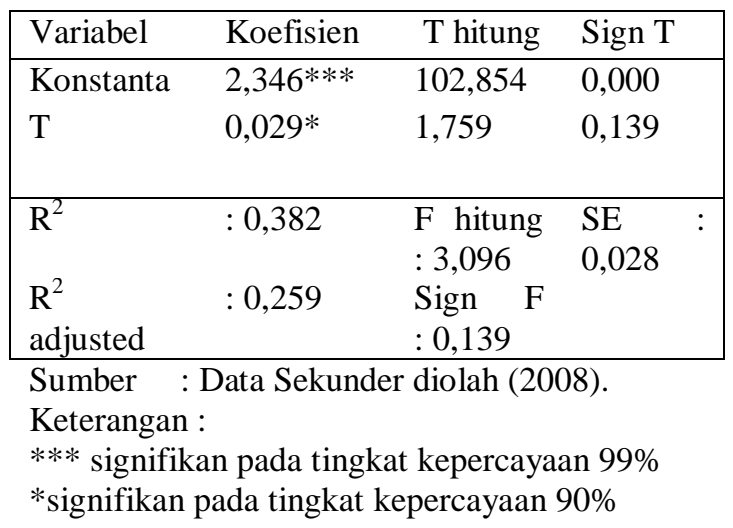

Hasil uji t menunjukkan bahwa konstanta $\mathrm{T}$ signifikan pada tingkat kepercayaan $90 \%$. $\mathrm{R}^{2}$ persamaannya adalah 0,382 artinya bahwa 38,2\% variasi kontribusi subsektor kehutanan dapat dijelaskan oleh variabel waktu yang di masukkan dalam model, sedangkan 61,8\% dapat dijelaskan oleh variabel lain. Garis trend yang positif menunjukkan bahwa kontribusi subsektor kehutanan terhadsap PDRB cenderung meningkat selama periode penelitian (2000-2006). 


\section{Subsektor Perikanan}

Trend subsektor perikanan mengikuti pola trend linier, uji persamaannya adalah signifikan pada tingkat kepercayaan 99\%. Hasil analisis subsektor perikanan lengkapnya dapat dilihat pada tabel Anova dibawah ini.

Tabel 7. Variabel, Koefisien dan Hasil

Perhitungan Anova

Kontribusi Subsektor

Perikanan PDRB

Maluku Utara Tahun 2000-2006.

\begin{tabular}{|c|c|c|c|}
\hline Variabel & Koefisien & T hitung & Sign T \\
\hline Konstanta & $5,023 * * *$ & 195,033 & 0,000 \\
\hline $\mathrm{T}$ & $\overline{-}-052^{* * *}$ & $-9,055$ & 0,000 \\
\hline $\mathrm{R}^{2}$ & : 0,943 & $\begin{array}{l}\text { F hitung } \\
81.985\end{array}$ & $\begin{array}{l}\text { SE } \\
0.030\end{array}$ \\
\hline $\begin{array}{l}\mathrm{R}^{2} \\
\text { adjusted }\end{array}$ & : 0,931 & $\begin{array}{l}\text { Sign F } \\
0,000\end{array}$ & \\
\hline
\end{tabular}

Hasil uji t menunjukkan bahwa konstanta $\mathrm{T}$ signifikan pada tingkat kepercayaan 99\%. $\quad \mathrm{R}^{2}$ persamaannya adalah 0,943 artinya bahwa 94,3\% variasi kontribusi subsektor perikanan dapat dijelaskan oleh variabel waktu yang dimasukkan dalam model, sedangkan 5,7\% dapat dijelaskan oleh variabel lain. Garis trend yang negatif menunjukkan bahwa kontribusi subsektor perikanan terhadap PDRB cenderung menurun. Potensi laut yang dimiliki namun pengolahan hasil laut yang menggunakan tekmologi sederhana, penangkapan hasil laut yang menggunakan bom ikan mengancam biota laut dan pelestarian hasil laut, sehingga kontribusi subsektor perikanan pada masa yang akan datang menurun.

Dari uraian hasil analisis dan pembahasan trend sektor pertanian PDRB Provinsi Maluku Utara, maka hasil tersebut dapat dirangkum seperti tabel 3.2.7.

Tabel 8. Trend Kontribusi Dirinci Per Sektor Pertanian PDRB Provinsi Maluku Utara Tahun 2000-2006.

\begin{tabular}{|l|l|l|l|}
\hline Sektor & Konstanta & $\mathrm{T}$ & $\mathrm{T}^{2}$ \\
\hline Pertanian & $35,226^{* * *}$ & $0,478^{* *}$ & $-0,071^{* *}$ \\
\hline $\begin{array}{l}\text { Tanaman } \\
\text { Pangan }\end{array}$ & $10,084^{* * *}$ & $-0,131^{* * *}$ & \\
\hline Perkebunan & $16,995^{* * *}$ & $0,386^{* *}$ & \\
\hline Peternakan & $1,514^{* * *}$ & $0,032^{* *}$ & $-0,007^{* *}$ \\
\hline Kehutanan & $2,346^{* * *}$ & $0,029^{*}$ & \\
\hline Perikanan & $5,023^{* * *}$ & $-0,052^{* * *}$ & \\
\hline
\end{tabular}

Sumber : Data Sekunder diolah(2008).

Keterangan :

*** signifikan pada tingkat kepercayaan 99\%

** signifkan pada tingkat kepercayaan 95\%

* signifkan pada tingkat kepercayaan 90\%

Tabel 8, menunjukkan bahwa kontribusi sektor pertanian menunjukkan kecendrungan garis trend yang negatif, artinya bahwa trend kontribusi PDRB sektor pertanian menurun dan signifikan pada tingkat kepercayaan 95\%. Subsektor tanaman pangan trend kontribusi yang menurun dan signifikan pada tingkat kepercayaan 99\%, subsektor perkebunan menunjukkan garis trend yang positif artinya bahwa kontribusi PDRB subsektor perkebunan meningkat dan signifikan pada tingkat kepercayaan 95\%. Subsektor peternakan kecendrungan trend menurun dan signifikan pada tingkat kepercayaan 95\%, subsektor kehutanan garis trend yang positif menunjukkan bahwa kontribusi subsektor kehutanan meningkat dan signifikan pada tingkat kepercyaan 90\%, dan subsektor perikanan trend cenderung menurun dan signifikan pada tingkat kepercayaan $99 \%$. 
Sektor pertanian dan subsektor yang mengikuti trend pola kuadratik adalah sektor pertanian dan subsektor peternakan, sedangkan subsektor tanaman pangan,dan perikanan mengikuti pola trend linier, subsektor perkebunan dan kehutanan mengikuti trend logaritmik.

\section{KESIMPULAN}

Berdasarkan hasil penelitian tentang " Analisis Subsektor Unggulan Pertanian di Provinsi Maluku Utara, maka dapat ditarik kesimpulan bahwa Berdasarkan perhitungan LQ sektor pertanian, subsektor tanaman pangan, perkebunan, kehutanan dan perikanan merupakan subsektor unggulan. namun keunggulan alokasi yang bernilai negatif menunjukkan bahwa subsektor perkebunan tidak memiliki keunggulan alokasi tapi memiliki keunggulan kompetitif, sehingga subsektor perkebunan merupakan subsektor unggulan pada sektor pertanian di Provinsi Maluku Utara. Dari analisis trend kontribusi sektor pertanian menunjukkan kecendrungan garis trend yang negatif, artinya bahwa trend kontribusi PDRB sektor pertanian menurun.

\section{DAFTAR PUSTAKA}

Ariyani, A.H.M. 2005. Peran dan Identifikasi Komoditas Pertanian Unggulan di Kabupaten Wonogiri. Tesis Magister Manajemen Agribisnis. Universitas Gadjah Mada. Yogyakarta. Unpublished.

BAPPEDA, 2006. 7 Tahun Maluku Utara Membangun. Ternate.
BPS, 2005. Produk Domestik Regional Bruto Provinsi Maluku Utara. Ternate.

Sjafrijal, 1997. Pertumbuhan Ekonomi dan Ketimpangan Regional Wilayah Indonesia Bagian Barat LP3ES.

Tarigan, R. 2005. Ekonomi Regional : Teori dan Aplikasi. Edisi Revisi. Bumi Aksara. Jakarta.

Widodo,T. 2006. Perencanaan Pembangunan : Aplikasi Komputer (Era Otonomi Derah).UPP STIM YKPN. Yogyakarta.

Zam S, 2002. Penentuan Subsektor Unggulan Untuk Pembangunan Ekonomi Kota Pekanbaru, Tesis Magister Ekonomi Pembangunan. Universitas Gadjah Mada. Yogyakarta. Unpublished. 